\title{
SPHINX LIGUSTRI.
}

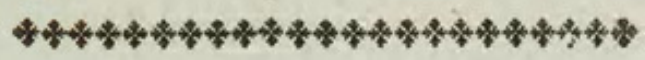

CHARACTER GENERICUS.

Antenne fubprifmaticæ, utroque fine attenuatæ. Lingua exferta (plerifque.)

$P$ alpi duo reflexi.

Ala deflexx.

Lin. Syf. Nat. Gmel. p. 2371.

CHARACTER SPECIFICUS, Ec.

SPHINX alis integris: pofticis incarnatis fafciis nigris, abdomine rubro cingulis nigris.

Lin. Syft. Nat. p. 799.

S. fpirilinguis, alis fuperioribus fufcis, inferioribus abdomineque fafciis tranfverfis rubris.

Geoffr. ins. 2. p. 84. 7 .

Raj. ins. 144. n. I.

Goed. ins. 1. p. 93. t. 24.

Liff. Goed. 75 . f. 25 .

Reaum. ins. 2. t. 20. f. 1-4.

Folia liguftri præcipue amat larva infecti hujus pulcherrimi. Ineunte Augufto fub humo in chryfalidem convertitur, e qua menfe Junio vel Julio infequentis anni erumpit Sphinx perfecta. 


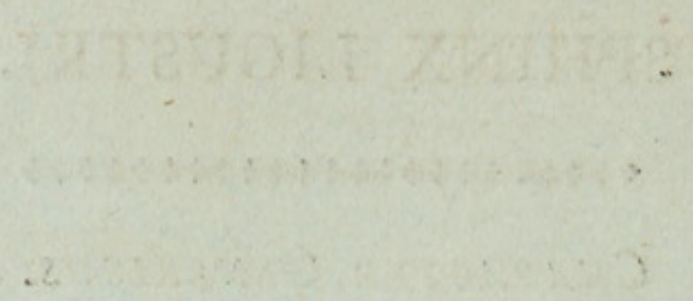






\section{THE PRIVET SPHINX.}

\section{GENERIC CHARACTER.}

Antenne fubprifmatic, attenuated at each end. Tongue (generally) exferted.

Feelers two.

Wings deflected.

\section{SPECIFIC CHARACTER, ËC.}

Brown SPHINX, with the lower wings and body rofe-colored, ftriped with black bands. The PRIVET Hawk-Moth. Alb. ins. p. 7 .

Roes. 3.

Merian Europ. 124.

The caterpillar of this beautiful infect feeds chiefly on the leaves of the Privet. In the beginning of Auguft it retires under ground to undergo its change into a chryfalis, from which in June or July in the following year emerges the infect in its complete or ultimate form. 


\section{$2 \mathrm{BHL}$ Biodiversity Heritage Library}

Shaw, George. 1800. "The Privet Sphinx, Sphinx ligustri [PI. 443]." The Naturalist's Miscellany 11(CXXXII), https://doi.org/10.5962/p.310890.

View This Item Online: https://www.biodiversitylibrary.org/item/276496

DOI: https://doi.org/10.5962/p.310890

Permalink: https://www.biodiversitylibrary.org/partpdf/310890

\section{Holding Institution}

Museums Victoria

\section{Sponsored by}

Atlas of Living Australia

\section{Copyright \& Reuse}

Copyright Status: Public domain. The BHL considers that this work is no longer under copyright protection.

This document was created from content at the Biodiversity Heritage Library, the world's largest open access digital library for biodiversity literature and archives. Visit BHL at https://www.biodiversitylibrary.org. 